\title{
Clumping of Susceptible Bacteria by Bacteriophage Tail Fibres
}

\author{
By P. WILDY* \\ Institute of Virology, University of Glasgow, Scotland \\ AND T. F. ANDERSON \\ The Institute for Cancer Research, Fox Chase, Philadelphia, Pa. \\ (Received 19 July 1963) \\ SUMMARY \\ Susceptible bacteria are clumped in the presence of purified chemically- \\ separated T-even tail fibres. The clumping is partially host-specific, \\ serologically specific, and dependent upon the ionic environment. The \\ clumping principle is adsorbed by bacterial suspensions with coincident \\ disappearance of tail fibres. Clumping is believed to be caused mainly by \\ phage tail fibres and the evidence suggests that the mechanism is by the \\ formation of bridges between bacteria. It is inferred that the tail fibre \\ must have at least two adsorbing sites.
}

\section{INTRODUCTION}

The T-even series of bacteriophages are known to attach to susceptible bacteria by the tips of their tails (Anderson, 1953; Kellenberger \& Arber, 1955; Williams \& Fraser, 1956). The tails of these viruses are complex structures comprising several proteins different from that of the phage head (Levinthal \& Fisher, 1952; Lanni \& Lanni, 1953; De Mars, Luria, Levinthal \& Fisher, 1953; Anderson, Rappaport \& Muscatine, 1953). Electron micrographic studies show at least four structures: tail pins, sheaths, base plates and fibres (Williams \& Fraser, 1956; Brenner et al. 1959). The finding that separated tail fibres adsorb to susceptible bacteria (Williams \& Fraser, 1956) suggested that tail fibres might determine the attachment of bacteriophage. This idea is supported by a number of observations which will be discussed later, but it is probable from Franklin's (1961) results that specific attachment is not mediated solely by fibres. Brenner et al. (1959) have developed methods for separating and purifying bacteriophage components; hence it is now possible to study the properties of isolated fibres. We have studied some interactions of such preparations with bacterial suspensions and this paper records experiments on the bacterial clumping that may result.

\section{METHODS}

Bacterial suspensions. The following bacterial strains were used: Escherichia coli strain B (Luria), which is susceptible to infection by both bacteriophages $T_{2}$ and $T_{4}$, and two independently-arisen phage-resistant bacterial strains $B / 2_{1}$ and $B / 2_{2}$, which

* Present address: Department of Virology and Bacteriology, University of Birmingham, England. 
are resistant to bacteriophage $\mathbf{T}_{2}$. All bacteria were grown in aerated nutrient broth to give concentrations of about $10^{9} / \mathrm{ml}$. Living cultures of bacteria were used in a few experiments, but unfortunately they were prone to spontaneous clumping and were therefore unsatisfactory. Accordingly standard suspensions of killed organisms were made. One volume of $40 \%(w / v)$ formaldehyde was squirted rapidly into four volumes of a well-grown broth culture. After $5 \mathrm{~min}$. at room temperature (about $\left.30^{\circ}\right)$ the formolized cultures were centrifuged at $3500 \mathrm{rev} \cdot / \mathrm{min}$. $(=2000 \mathrm{~g})$ for $20 \mathrm{~min}$. The deposited bacteria were washed twice in nutrient broth, resuspended in broth, and allowed to stand at $4^{\circ}$ overnight. The supernatant fluid containing mostly individual bacteria was then carefully sucked off and stored in the refrigerator. This standard suspension of $\boldsymbol{E}$. coli B was counted by using a Petroff Hauser chamber and had $2 \times 10^{9}$ organisms $/ \mathrm{ml}$. The other strains were adjusted to the same optical density. These suspensions which all contained about $96 \%$ single unclumped organisms remained stable for the duration of the experiments ( 2 weeks).

Tail fibre preparations. We are indebted to Dr Naomi Franklin for preparations of tail fibres made from bacteriophages $T_{2}$ and $B \times T_{4}$ (Streisinger, 1956) by the method of Brenner et al. (1959). The latter phage was derived by crossing phages $T_{2}$ and $T_{4}$ and then serially backcrossing progeny possessing $T_{4}$ host range with phage $T_{2}$ (Streisinger, 1956). It was used because it is possible to obtain from it good yields of tail fibres with the host range and serological specificities of phage $T_{4}$. Concentrates of bacteriophage were treated in a solution containing $0 \cdot 14 \mathrm{M}$-glycine and $0 \cdot 1 \mathrm{M}-\mathrm{NaCl}$ at $\mathrm{pH} \mathrm{2}$. This was followed by digestion with $10 \mathrm{mg} . / \mathrm{ml}$. DNase for $2 \mathrm{hr}$ at room temperature and at about $\mathrm{pH} \mathrm{7} \cdot 4$ with about $0.005 \mathrm{M}-\mathrm{MgSO}_{4}$. The digest was then spun at $2000 \mathrm{~g}$ for $30 \mathrm{~min}$. The resulting pellet was suspended in $1.0 \mathrm{ml} .2 \%(\mathrm{w} / \mathrm{v}) \mathrm{NaH}_{2} \mathrm{CO}_{3}(\mathrm{pH} 7 \cdot 8)$ and digested with trypsin $50 \mathrm{mg} . / \mathrm{ml}$. and chymotrypsin $50 \mathrm{mg} . / \mathrm{ml}$. overnight at $23^{\circ}$. More enzyme was added and the tubes incubated at $37^{\circ}$ for another $30 \mathrm{~min}$. The now clear solution was centrifuged at $40,000 \mathrm{rev} . / \mathrm{min} .(=100,000 \mathrm{~g})$ in the SW 39 head of a Spinco model L centrifuge for $90 \mathrm{~min}$. The resulting supernatant fluids had abundant tail fibres as seen by negative contrast electron microscopy.

Gamma globulins. Gamma globulins were prepared by ammonium sulphate treatment from rabbit sera made against bacteriophages $T_{2}$ and $T_{4}$. These were absorbed with bacteria before use. Organisms from a freshly grown broth culture of Escherichia coli B were sedimented by centrifuging at $3500 \mathrm{rev} . / \mathrm{min}$. $(=2000 \mathrm{~g})$ for $20 \mathrm{~min}$. The bacteria were washed by resuspending in broth and sedimenting in $30 \times 5 \mathrm{~mm}$. tubes to give about $10^{10}$ organisms/tube. These were resuspended in the globulin preparation and allowed to react at $30^{\circ}$ for $15 \mathrm{~min}$. Most of the bacteria were then sedimented at $3500 \mathrm{rev} . / \mathrm{min}$. $(=2000 \mathrm{~g}$ ) for $20 \mathrm{~min}$. and the supernatant fluid finally cleared of bacteria by centrifuging at $6000 \mathrm{rev} . / \mathrm{min}$. $(=5800 \mathrm{~g})$ for $20 \mathrm{~min}$.

Experimental procedure. Owing to the small volume of material available all experiments were carried out on a micro-scale. Volumes were always measured with micropipettes delivering $0.015 \mathrm{ml}$. constructed from Pyrex glass. All reactions were carried out in test tubes having internal dimensions of $50 \times 5 \mathrm{~mm}$.

Except where otherwise specified, readings of all experiments on clumping were made after mixing equal volumes of an appropriate dilution of tail fibres (in broth) with the standard suspension of bacteria at $4^{\circ}$. After $1 \mathrm{hr}$ at $4^{\circ}$ the mixture was 
diluted $1 / 5$ in broth, mounted in an unruled chamber $\frac{1}{10} \mathrm{~mm}$. deep, and random fields examined by dark ground microscopy. The proportions of bacteria that occurred in clumps were thus directly determined. At least 300 bacteria were counted for each determination.

In eighteen experiments, the average percentage of clumped bacteria in control suspensions was $3.82 \%$ with a standard deviation, $\sigma=\mathbf{1 . 6 6} \%$. Thus, the probability of any values exceeding $8.8 \%$ by chance was $<0.001$. Because of the obvious difficulty in estimating the number of bacteria aggregated in large clumps, several estimates were always made of the proportion of bacteria clumped in the presence of tail fibres in each sample (e.g. four replicate determinations on one sample gave a mean of $38 \%$ clumped, with $\sigma=\mathbf{5} \cdot 8 \%$ ). However, the proportion of bacteria clumped by a particular dilution of tail fibres varied considerably in different experiments; this may be attributable to inaccuracies arising from handling small volumes and there were probably also other uncontrolled variables. We have therefore not attempted to develop an absolute titration procedure but have depended on the internal controls built into each experiment.

Electron microscopy. Negatively stained preparations of tail fibres were made by using potassium silicotungstate as described for potassium phosphotungstate (Anderson, 1962). They were examined in a Siemens Elmiskop I.

\section{RESULTS}

Clumping of susceptible bacteria by tail fibre preparations

It was soon found that suitable dilutions of tail fibres would clump formolized suspensions of bacteria. The first series of experiments was designed to show whether this agglutination was specifically caused by tail fibres or not.

Table 1. Clumping of formolized and fresh suspensions of Escherichia coli strain $B$ by phage $T_{2}$ tail-fibre preparations and absorption of clumping principle by bacteria

$\begin{array}{ccc}\text { Additions to bacterial suspensions } & \begin{array}{c}\text { Standard } \\ \text { formolized } \\ \text { suspension }\end{array} & \begin{array}{c}\text { Fresh } \\ \text { bacterial } \\ \text { suspension }\end{array} \\ \text { Fibres diluted } 1 / 25 \text { in broth (1) } & \mathbf{5 2 \cdot 0} & \mathbf{4 6 \cdot 0} \\ \text { Broth control } & \mathbf{4 \cdot 2} & \mathbf{8 . 7} \\ \text { Supernatant fluids from (1) } & \mathbf{4 \cdot 3} & \mathbf{3 \cdot 8} \\ \text { after reacting for } 1 \mathrm{hr} \text { at } 4^{\circ} & & \end{array}$

Behaviour of fresh and formolized bacteria. In the first experiment the behaviour of fresh and formolized suspensions of Escherichia coli в were compared. Tail fibres diluted $1 / 25$ in broth were mixed with equal volumes of each suspension under the standard conditions. After $1 \mathrm{hr}$ at $4^{\circ}$ samples were taken and the proportions of clumped bacteria determined. The remainder of the mixtures were centrifuged at $\mathbf{3 5 0 0} \mathrm{rev} . / \mathrm{min}$. for $\mathbf{2 0} \mathrm{min}$., and the supernatant fluids tested for residual activity by using the standard formolized suspension of bacteria. The results are shown in Table 1. Both fresh and formolized suspensions were clumped in the presence of fibres and both evidently absorbed the clumping principle. Formolized and fresh 
bacteria thus behaved similarly and all remaining experiments were made with the standard formolized suspension for reasons already given (Methods).

Coincident disappearance of tail fibres and of clumping principle. It would be desirable to show that tail fibres and clumping principle were absorbed in the same proportions when mixed with susceptible bacteria. Unfortunately tail fibres were uncountable. However, we were able to make the following comparisons. A 1/10 dilution of the tail fibre preparation in distilled water was examined in the electron

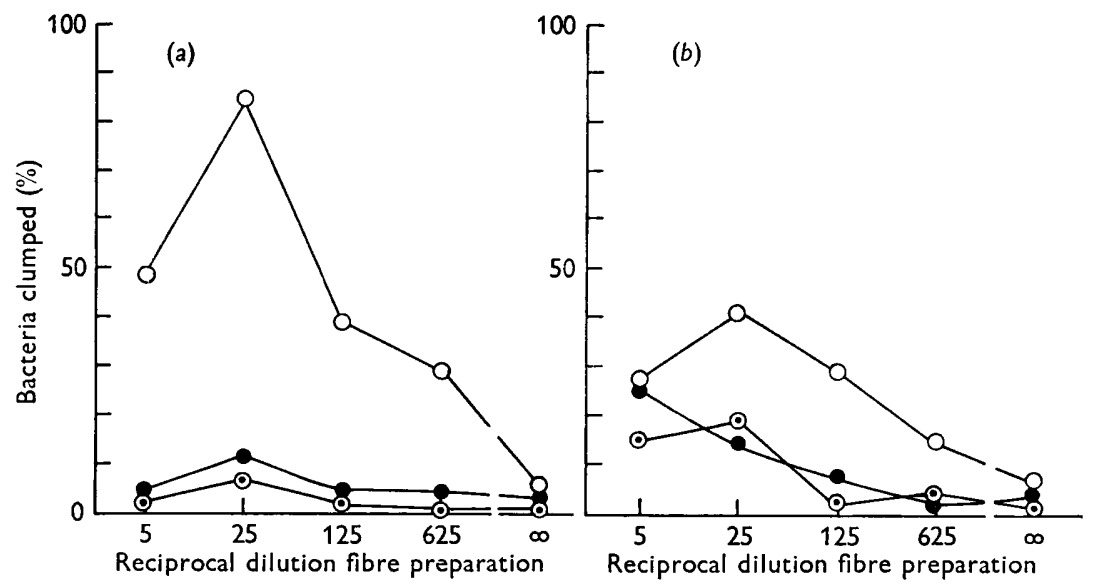

Fig. 1. Percentage bacteria clumped in suspension of Escherichia coli $\mathrm{B}, \mathbf{B} / \mathbf{2}_{1}$ and $\mathrm{B} / \mathbf{2}_{\mathbf{2}}$ by purified tail fibres of (a) phage $\mathbf{T}_{2}$ and $(b)$ phage $\mathbf{B} \times \mathbf{T}_{4} . \bigcirc, E$. coli $\mathbf{B} ; \mathcal{O}, \boldsymbol{E} . \operatorname{coli} \mathbf{B} / \mathbf{2}_{1}$; $\odot$, E. coli $\mathbf{B} / \mathbf{2}_{\mathbf{2}}$.

microscope at a magnification of 40,000. Many tail fibres were seen in each field, with an occasional tail sheath. A pellet made from the standard suspension containing about $1.2 \times 10^{8}$ formolized bacteria was resuspended in $0.06 \mathrm{ml}$. of the 1/10 fibre dilution and left at $4^{\circ}$ for $1 \mathrm{hr}$, and then the bacteria sedimented. No fibres whatsoever were found in the supernatant fluid. The original tail fibre dilution clumped $44.0 \%$ of the bacteria, but after absorption clumped only $7 \%$. This result shows that the loss of fibres was matched by a loss in clumping activity.

Host cell specificity. Bacteriophage $\mathrm{T}_{2}$ will infect Escherichia coli в highly efficiently but will not infect the $\mathbf{B} / 2$ strains whose resistance is attributable to a lack of adsorption of the phage. To see whether $\mathbf{T}_{2}$ tail fibres could clump the resistant bacteria, several fivefold dilutions of tail fibres were mixed with suspensions of the resistant strains, $\mathrm{B} / \mathrm{2}_{1}$ and $\mathrm{B} / \mathrm{2}_{2}$, in parallel with the standard suspension of strain $\mathrm{B}$. The results are shown in Fig. 1a. Although significant clumping of the susceptible bacteria occurred in the presence of tail fibres diluted as much as $1 / 625$, a prozone phenomenon was noted in which less clumping was produced by the $1 / 5$ dilution than by the $1 / 25$ dilution. Neither of the resistant strains was much clumped. It will, however, be noted that at a dilution of $1 / 25$ there was an increase in the proportion of clumped $\mathrm{B} / \mathbf{2}_{1}$ and $\mathrm{B} / \mathbf{2}_{2}$ over the control. The probability of this having occurred by chance is very low $(P=<0.001)$ since with each suspension the proportions of clumped bacteria exceeds the mean of controls by more than three standard deviations. The results therefore suggest that significant clumping occurred 
with the two insusceptible strains at a dilution of $1 / 25$ tail fibres, but to an extent that was small compared with the clumping that occurred with the standard suspension of susceptible bacteria.

Two questions arose from the above results. First, had the suspensions of Escherichia coli в/2 failed to clump because the organisms were deficient in specific $\mathrm{T}_{2}$ receptors or were they inagglutinable for some other reason? Secondly, does the small amount of clumping observed with the resistant strains reflect poor but significant adsorption of tail fibres? The first question was answered by showing that the suspensions of $\boldsymbol{E}$. coli $\mathrm{B} / \mathbf{2}$ were indeed clumped by tail fibres with $\mathrm{T}_{\mathbf{4}}$ host range. Several fivefold dilutions of $\mathrm{B} \times \mathrm{T}_{4}$ tail fibres were made in broth and were tested against the same formolized suspensions. The results are shown in Fig. $1 b$, and show that $\mathrm{B} \times \mathrm{T}_{4}$ tail fibres did agglutinate $\mathrm{B} / 2$ though they were more active in clumping the standard suspension of $\boldsymbol{E}$. coli B.

Table 2. Absorption of clumping principle from preparations of $\boldsymbol{T}_{2}$ tail fibres by three strains of Escherichia coli

\begin{tabular}{|c|c|}
\hline $\begin{array}{c}\text { 1/25 } \mathrm{T}_{2} \text { tail-fibre preparation } \\
\text { absorbed with }\end{array}$ & $\begin{array}{c}\text { Percentage of } \\
E . \text { coli B clumped } \\
\text { by absorbed tail- } \\
\text { fibre preparations }\end{array}$ \\
\hline $\begin{array}{l}\text { Broth (control) } \\
E . \operatorname{coli} \mathrm{B} \\
E . \operatorname{coli} \mathrm{B} / \mathbf{2}_{1} \\
E . \operatorname{coli} \mathrm{B} / \mathbf{2}_{2}\end{array}$ & $\begin{array}{r}31 \cdot 0 \\
3 \cdot 8 \\
9 \cdot 0 \\
15 \cdot 0\end{array}$ \\
\hline Control with no tail fibres & 4.2 \\
\hline
\end{tabular}

The second question was answered by using freshly-prepared bacterial suspensions of the same three strains to absorb tail fibres. A 1/25 dilution of the $T_{2}$ tail fibres preparation was mixed with equal volumes of each bacterial suspension in broth containing $2 \times 10^{9}$ bacteria $/ \mathrm{ml}$. After $1 \mathrm{hr}$ at $4^{\circ}$ the tubes were centrifuged at $3500 \mathrm{rev} . / \mathrm{min}$. $(=2000 \mathrm{~g})$ and residual clumping activity in the supernatant fluid estimated with the standard formolized suspension of Escherichia coli в. The results are given in Table 2. No residual clumping activity was detected after absorption with $E$. coli B while diminished but significant clumping occurred after absorption with the resistant strains. The results suggest, therefore, that $T_{2}$ tail fibres are absorbed more efficiently by $\boldsymbol{E}$. coli $\mathrm{B}$ than by its phage-resistant variants, and that clumping is therefore correspondingly increased. Neither effect is, however, absolutely specific.

Salt effect. Hershey, Kalmanson \& Bronfenbrenner (1944) showed that $\mathrm{T}_{2}$ bacteriophage requires cations for adsorption to its host, which suggested that clumping might also depend on the presence of cations. Accordingly, plain broth (to serve as a control) and a $1 / 17$ dilution of the $T_{2}$ tail fibre preparation in broth were both dialysed for $3 \mathrm{hr}$ against tap water at $20^{\circ}$ and then against distilled water at $4^{\circ}$ for a further $7 \mathrm{hr}$. A series of twofold dilutions of $1 \cdot 0 \mathrm{M}-\mathrm{NaCl}$ were made in distilled water. Equal volumes of dialysed bacteria and dialysed fibres were mixed with two volumes of appropriate dilutions of sodium chloride. For controls, dialysed broth was substituted for the tail fibre preparation. The results are given in Fig. 2. Clearly in the controls without tail fibres, significant clumping was only found in the 
presence of $0.4 \mathrm{M}-\mathrm{NaCl}$. In the presence of the tail fibre preparation, however, significant clumping was found under all conditions, but it was plainly very much less in the absence of added salt and was maximal in the presence of $0.025 \mathrm{M}-\mathrm{NaCl}$. The maximal and minimal values fall outside three standard deviations from the mean of the remaining values; the probability that these arose by chance is small $(P=<\mathbf{0 . 0 0 1})$. The absorption of clumping activity by bacteria in the absence of a salt was not tested.

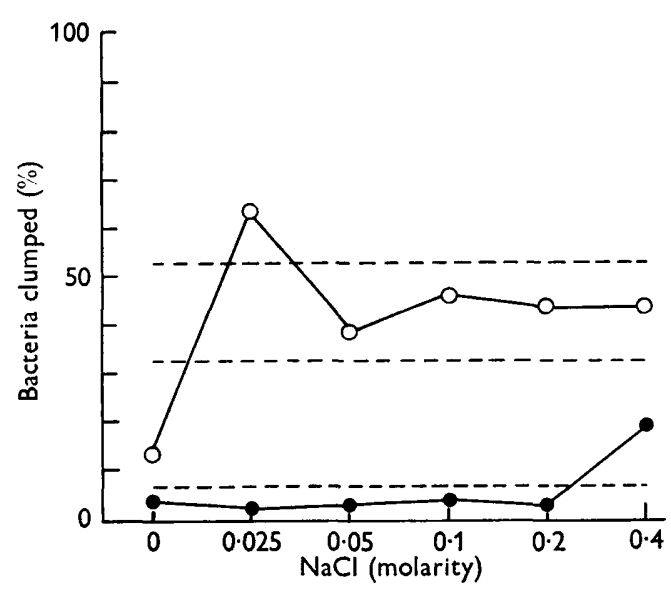

Fig. 2

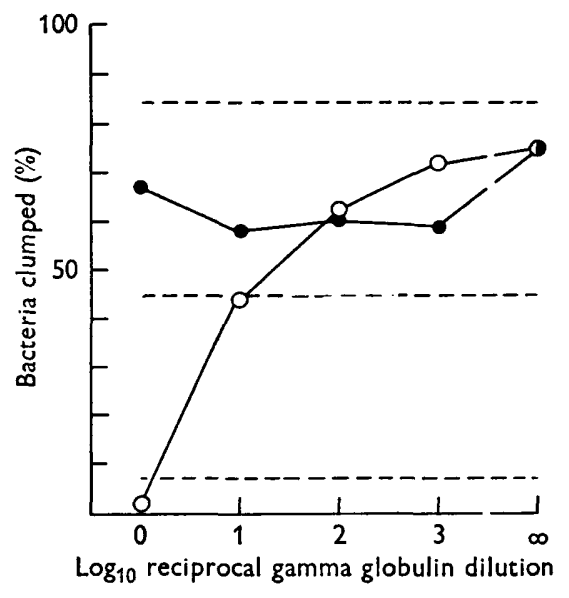

Fig. 3

Fig. 2. Effect of $\mathrm{NaCl}$ concentration on clumping of Escherichia coli $\mathrm{B}$ by phage $\mathrm{T}_{2}$ tail fibre preparation. $O$, Dialysed $T_{2}$ fibre preparation $1: 17$; $O$, dialysed broth.

Fig. 3. Inhibition of clumping activity of $T_{2}$ tail fibres by previous treatment with anti$\mathbf{T}_{2}(O)$ or anti- $\mathbf{T}_{4}(\Theta)$ gamma globulin.

Neutralization of clumping activity by antibody. Tenfold dilutions of anti- $\mathrm{T}_{2}$ and anti- $T_{4}$ gamma globulin were made in broth. Equal volumes of these and a $1 / 25 T_{2}$ fibre preparation were incubated at $4^{\circ}$ for $1 \mathrm{hr}$. The mixtures were then tested for ability to clump the standard bacterial suspension in the usual way. The results are given in Fig. 3. Treatment of $T_{2}$ fibres with undiluted anti- $T_{2}$ gamma globulin clearly neutralized clumping completely. Treatment with the $1 / 10$ dilution of anti- $T_{2}$ gamma globulin gave a percentage of clumping about three standard deviations less than the mean of all the remaining points, so that the probability that this arose by chance is small $(P=<\mathbf{0 . 0 0 1})$. Thus it is clear that antibody specific for $\mathbf{T}_{2}$ phage neutralized the clumping activity by $\mathbf{T}_{2}$ tail fibres. On the other hand, heterologous anti- $\mathrm{T}_{4}$ gamma globulin had a negligible effect.

Enhancement of clumping by antibody. We have seen that $\mathbf{T}_{2}$ tail fibres clumped susceptible bacteria, that the clumping factor was absorbed during the process, and that clumping was neutralized by homologous anti-phage antibody. It seemed possible that such antibody would enhance clumping of bacteria which had previously been treated with the tail-fibre preparations. Mixtures were therefore made of fivefold dilutions of the $\mathbf{T}_{2}$ tail-fibre preparation and the standard formolized suspension of Escherichia coli $\mathrm{B}$. After $1 \mathrm{hr}$ at $4^{\circ}$ each mixture was divided as follows: (1) one portion was diluted $1 / 5$ in broth and the proportion of clumped 
bacteria determined; (2) another portion was centrifuged at $3600 \mathrm{rev} . / \mathrm{min}$. $(=2000 \mathrm{~g}$ ) for $20 \mathrm{~min}$. and the supernatant fluid tested for residual clumping activity; (3) other portions were mixed with equal volumes of undiluted anti- $\mathbf{T}_{2}$ gamma globulin, $\mathbf{1} / 10$ anti- $\mathbf{T}_{2}$ gamma globulin, or (in one instance) undiluted anti- $\mathbf{T}_{4}$ gamma globulin. These were left for $1 \mathrm{hr}$ at $4^{\circ}$ and then read in the usual way. The results are given in Fig. $4 a$. It will be seen: (1) that when broth was added as a control, direct clumping with a prozone was observed much as in Fig. 1, though to a lesser extent; (2) that no significant clumping was induced by the supernatant fluids added to fresh bacteria; (3) that both dilutions of anti- $T_{2}$ gamma globulin
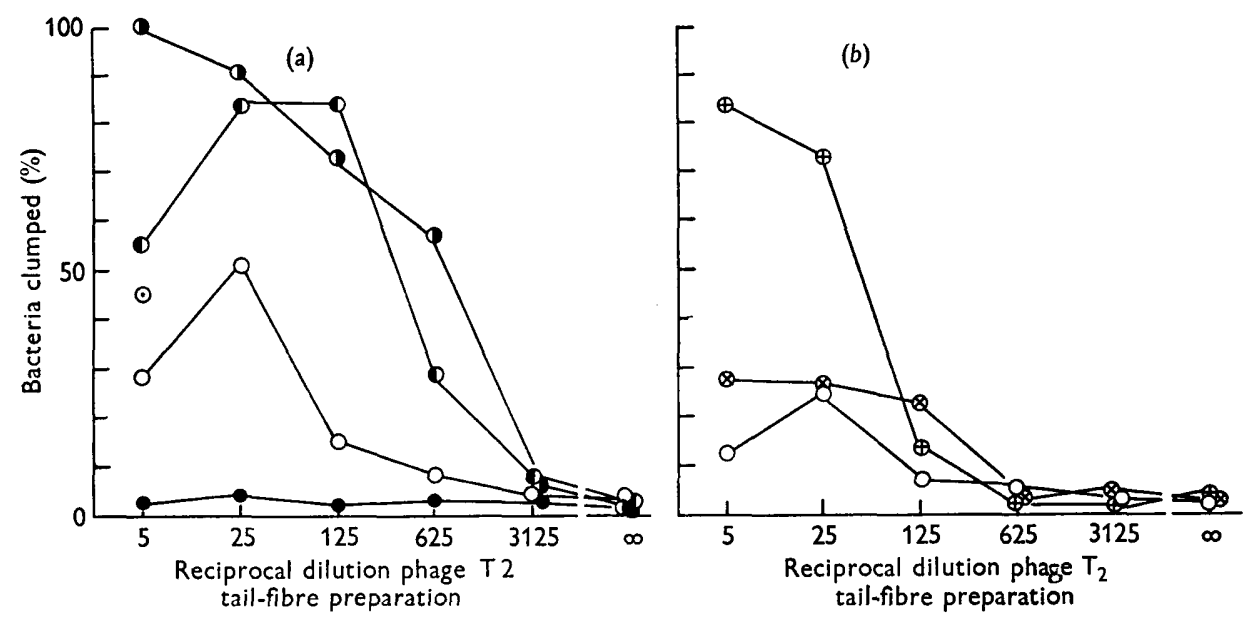

Fig. 4. The prozone phenomenon and its abolition. (a) Dilutions of tail fibres were mixed with Escherichia coli $B$ in standard fashion and the degree of clumping measured (O). In the process clumping principle was absorbed from the fluid (O). Upon adding anti- $T_{2}$ gamma globulin (undiluted $\odot$ or diluted 1/10 D) the prozone is abolished or diminished. Undiluted anti- $\mathrm{T}_{\mathbf{4}}$ gamma globulin had a smaller effect $(\odot)$. (b) The prozone may also be abolished by adding subsequently more $\boldsymbol{E}$. coli в $(\oplus)$. A much smaller effect is seen when $E$. coli $\mathbf{B} / \mathbf{2}_{1}(\otimes)$ was added. The standard curve is also shown $(O)$ calculated from data in Fig. $4 a$ assuming that no further clumping of bacteria would have occurred when more bacteria were added.

markedly increased the proportion of agglutinated bacteria but (as shown by additional controls) only when they had previously been exposed to the $\mathbf{T}_{\mathbf{2}}$ tail-fibre preparation; (4) that anti- $\mathrm{T}_{4}$ gamma globulin produced a much smaller increase in the proportion of clumped bacteria; this will be discussed. A similar less elaborate experiment showed a similar enhancement of clumping by $\mathrm{T}_{4}$ gamma globulin of bacteria coated with the $B \times \mathbf{T}_{4}$ tail-fibre preparation.

\section{The nature of clumping}

These results strongly suggested that clumping is specifically caused by some part of the bacteriophage, most probably by tail fibres which form bridges between bacteria. One feature which was constantly seen was a prozone (i.e. higher concentrations of the tail-fibre preparations clumped fewer bacteria than succeeding ones). This might be explained if it were assumed that, in the presence of excess tail fibres, most receptor sites on the bacteria became saturated before many bacterial collisions 
had occurred. This view is supported by the results given in Fig. $4 a$, where it will be seen that the prozone was completely abolished by adding homologous antibody. A further experiment supports the hypothesis. When the mixtures of bacteria and dilutions of the $T_{2}$ tail-fibre preparation had been incubated at $4^{\circ}$ for $1 \mathrm{hr}$, each was mixed with an equal volume of either the standard Escherichia coli в suspension or the standard $E$. coli $\mathrm{B} / 2_{1}$ suspension. After one further hour at $4^{\circ}$ the proportions of clumped bacteria were counted; the results are given in Fig. $4 b$. The control curve shows the proportion of agglutinated bacteria to be expected if no further clumping occurred (based on the curve in Fig. 4a). In fact, however, the experimental curves show that the presence of new bacteria of the susceptible strain $E$. coli B enormously increased the proportion of clumped bacteria and, in particular, that the prozone was abolished. The addition of $E$. coli $\mathrm{B} / \mathbf{2}_{1}$ organisms also increased the proportion of agglutinated bacteria, though to a slight extent. The significance of this increase is not clear.

\section{Abortive experiments}

Two abortive experiments should be mentioned. The most satisfactory demonstration that clumping was caused by tail fibres bridging bacteria would be directly by electron microscopy. No attempt was made to show this with whole bacteria or whole bacterial ghosts owing to the thick welt of silicotungstate surrounding the bacteria which would probably obscure the delicate tail fibres. Attempts have, however, been made to show bridging by using fragments of bacterial cell walls, so far without success. It might be expected that tail fibres could be eluted from bacteria by lowering the salt concentration. We have been unable to demonstrate this either by washing clumped bacteria or by dialysing them. Though both procedures reduced the proportions of clumped bacteria, no clumping principle was found to have been eluted.

\section{DISCUSSION}

The results reported here clearly indicate that some bacteriophage-specific factor-probably tail fibres-can clump bacteria. Such a phenomenon would be dependent upon two sequential processes: the adsorption of tail fibres to bacteria, and collisions between bacteria. Some of our experiments distinguished between these two processes. For example, the prozone phenomenon shows that it is possible to saturate bacterial sites with tail fibres before all the bacteria have had a chance to collide and clump. The experiment of Fig. $4 a$ shows that, even in the prozone region, all the detectable tail fibres were adsorbed to bacteria. This experiment also shows that such tail fibres have antigenic sites available for tail-fibre antibodies to link them together and thus form fibre-antibody-fibre bridges between saturated bacteria (Fig. 5). In addition, the experiment of Fig. $4 b$ shows that tail fibres on saturated bacteria also have adsorption sites available to form bridges to receptor spots on more bacteria added later.

Our findings may be compared with previously published data on the adsorption of tail fibres and bacteriophage to bacteria. Hershey et al. (1944) found that the efficiency of plating of phage $\mathrm{T}_{2}$ was maximal (1.0) in the presence of $0 \cdot 2 \mathrm{M}-\mathrm{NaCl}$, $0 \cdot 1$ with $0.03 \mathrm{M}-\mathrm{NaCl}$ and, in the absence of salt, was 0.001. Franklin (1961) reported that adsorption of serum-blocking power (which in her test was mostly a measure of tail-fibre antigens) was increased in low salt concentrations and was maximal at 
concentrations where adsorption of bacteriophage was virtually abolished. We made no direct measurements of the adsorption of clumping principle in different ionic environments, but clumping itself was much decreased in the absence of added sodium chloride while, in accord with Franklin's finding, most clumping was observed at the lowest concentration tested $(0.025 \mathrm{M})$. It seems therefore that the salt concentration optimal for clumping differs from that required for successful infection of bacteria.

It is not at all surprising that formolized suspensions of bacteria should absorb tail fibres as efficiently as fresh organisms because formalin does not inactivate the receptors of bacteriophage $T_{2}$ (Tolmach \& Puck, 1952; Puck \& Tolmach, 1954; Weidel, 1953).
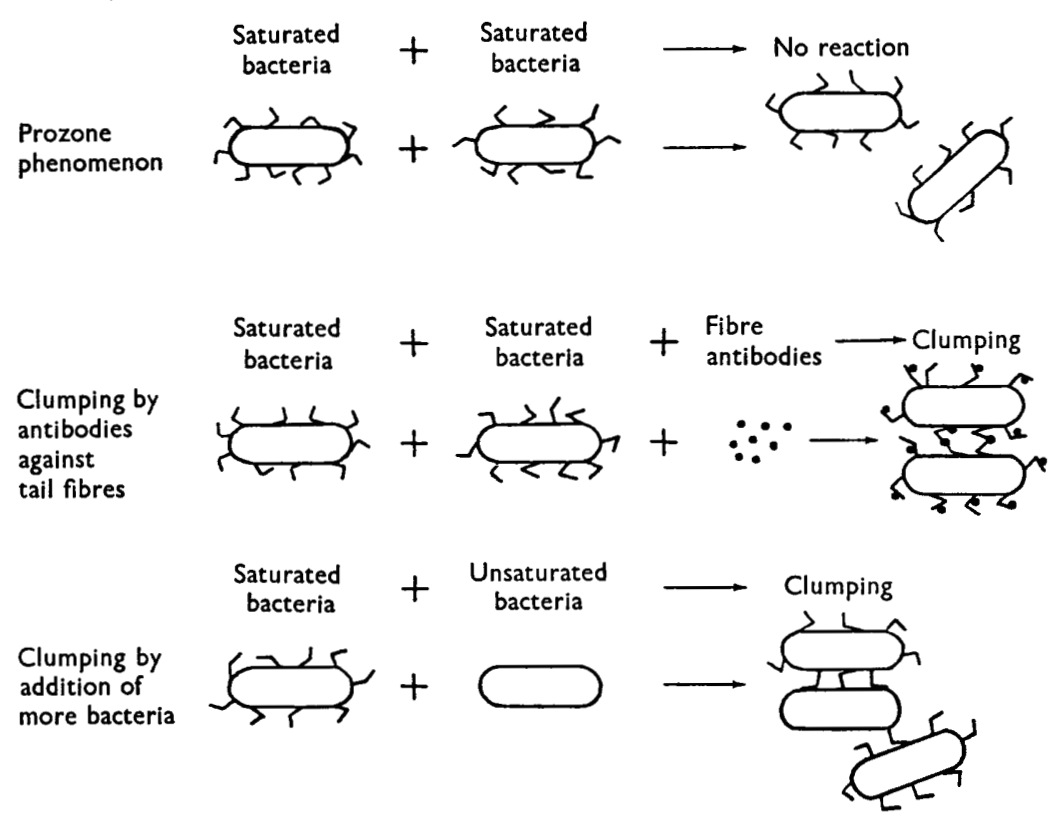

Fig. 5. Schematic diagram of the prozone phenomenon and its abolition by added tail-fibre antibodies and by adding more bacteria. The tail fibres and antibodies are drawn about five times too large relative to the bacteria and the antibody molecules are drawn as round balls for easy visibility in the diagram.

The question of how specifically tail fibres will adsorb to different host bacteria is of interest. Williams \& Fraser (1956) found that tail fibres from frozen and thawed bacteriophage adsorbed specifically, and Franklin (1961) quotes Streisinger's result with chemically separated fibres that $95 \% \mathbf{T}_{2}$ serum-blocking power adsorbs to Escherichia coli $\mathrm{B}$, whereas $<5 \%$ will adsorb to $\boldsymbol{E}$. coli $\mathrm{B} / \mathbf{2}$ under similar conditions. In contrast, her own finding was that the serum-blocking power of chemically separated fibres seemed to adsorb equally well to $E$. coli B and в/2, but the results were erratic. Our findings suggest partial specificity of clumping and adsorption of clumping principle. As a crude estimate, about $50 \%$ of the clumping principle was taken up by $E$. coli в/2 organisms. Only slight clumping of the $E$. coli в/2 strains was observed in the presence of $\mathrm{T}_{2}$ tail-fibre preparations. However, neither of the $E$. coli $\mathrm{B} / 2$ strains clumped as well as $E$. В coli in the presence of $\mathrm{B} \times \mathrm{T}_{4}$ tail fibres. 
These results, together with our own, suggest that much of the specificity of $T_{2}$ bacteriophage infection may be attributable to the tail fibres, but that this is not the whole story is plain from Franklin's (1961) results which show that the sheath is also involved.

The structure of the tail fibres of T-even bacteriophage is known to be complex. Brenner et al. (1959) showed that 'fingerprints' of purified tail fibres were elaborate and indicated, if the fibres are built entirely from repeating sub-units, that each subunit must have a molecular weight of about 100,000. From morphological studies each tail fibre might be expected to have a particle weight of about 400,000, suggesting four such sub-units. On the other hand, the fibre might be composed of a large number of dissimilar subunits. Antigenically the tail fibres are complex. Franklin's (1961) results indicate at least two 'epitopes' or determinative groups on the fibres, both of which possess serum-blocking power; one is specific for homologous phage and the other is shared by both phage types. In view of these findings, it is surprising that the neutralizing activity of clumping principle by antibody appears so specific. Perhaps the heterologous component is a minor one and our experiments were too crude to detect it. Indeed in Fig. $4 a$ some increase in clumping by addition of $\mathrm{T}_{4}$ antibody is shown. Unfortunately, this has not been repeated and it is not known if this is a significant increase. Perhaps the most important fact suggested by the work reported here is that clumping probably occurs by tail fibres which form bridges between bacteria, suggesting that each fibre must have at least two adsorption sites. If this be so, the tail fibre is a multiple structure in the chemical sense, the serological sense, and in the functional sense.

One of us (P. W.) wishes to thank Dr T. R. Talbot, jun., for facilities at the Institute for Cancer Research, Fox Chase, Philadelphia. We also wish to thank Dr Naomi Franklin, who provided the tail-fibre preparation and gamma globulin. The work was supported in part by a grant from the National Science Foundation, whilst one of us (P. W.) was a member of the Medical Research Council Unit for Experimental Virus Research.

\section{REFERENCES}

Anderson, T. F. (1953). The morphology and osmotic properties of bacteriophage systems. Cold Spr. Harb. Symp. quant. Biol. 18, 197.

Anderson, T. F. (1962). Negative staining and its use in the study of viruses and their serological reactions. In The Interpretation of Ultrastructure. Ed. by R. J. C. Harris, 1, 251. New York and London: Academic Press.

Anderson, T. F., Rappaport, C. \& Muscatine, N. A. (1953). On the structure and osmotic properties of phage particles. Annls. Inst. Pasteur, Paris, 84, 5.

Brenner, S., Streisinger, G., Horne, R. W., Champe, S. P., Barnett, L., Benzer, S. \& ReEs, M. W. (1959). Structural components of bacteriophage. J. Molec. Biol. 1, 281.

De Mars, R. I., Luria, S. E., Levinthal, C. \& Fisher, H. (1953). The production of incomplete bacteriophage particles by the action of proflavine and the properties of incomplete particles. Annls. Inst. Pasteur, Paris, 84, 113.

Franklin, N. C. (1961). Serological study of tail structure and function in coliphages $T_{2}$ and $T_{4}$. Virology, 14, 417.

Hershey, A. D., Kalmanson, G. \& Bronfenbrenner, J. (1944). Co-ordinate effects of electrolyte and antibody on infectivity of bacteriophage. J. Immunol. 48, 221.

Kellenberger, E. \& Arber, W. (1955). Die Struktur des Schwanzes der Phagen $T_{2}$ und $\mathbf{T}_{4}$ und der Mechanisms der irreversiblen Adsorption. Z. Naturf. 10b, 698. 
LANNI, F. \& LANNI, T. Y. (1953). Antigenic structure of bacteriophage. Cold Spr. Harb. Symp. quant. Biol. 18, 159.

Levinthal, C. \& Fisher, H. (1952). The structural development of a bacterial virus. Biochim. biophys. Acta, 9, 419.

Puck, T. T. \& Tolmach, L. J. (1954). Physicochemical studies on virus and cell surface groups. Archs. Biochem. 51, 229.

STREIsinger, G. (1956). The genetic control of host range and serological specificity in bacteriophages $T_{2}$ and $T_{4}$. Virology, 2,377 .

Tolmach, L. J. \& Puck, T. T. (1952). The mechanism of virus attachment to host cells. III. J. Am. chem. Soc. 74, 5551.

WeIDEL, W. (1953). Further studies on the membrane of ' $E$. coli B'. Annls. Inst. Pasteur, Paris, 84, 60.

Williams, R. C. \& Fraser, D. (1956). Structural and functional differentiation in $T_{2}$ bacteriophage. Virology, 2, 289. 